\title{
Pemanfaatan Aset Buah Pisang Lokal Menjadi Produk Jenang “Jepipet" di Desa Jampet Kecamatan Ngasem Kabupaten Bojonegoro
}

\author{
Abid Rohman, Aliyah, Fikri Aji Wicaksosmo \\ Universitas Islam Negeri (UIN) Sunan Ampel Surabaya \\ abidabufida@gmail.com
}

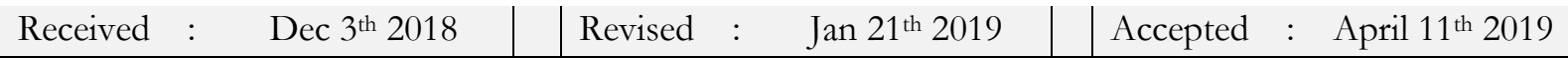

\begin{abstract}
To increase the economic and social independence, various efforts were carried out, it includes by providing assistance to the community. This research aims to provide assistance to the community in the village of Jampet, Bojonegoro Regency, by utilizing local banana assets for making Jenang Jepipet as an original snack made from bananas from Jampet villages. The collaborative and partnership efforts built between the universities together with the Jampet villagers as a manifestation of the practice of university community engagement. By using Asset-Based Community Development $(A B C D)$ approach, this research is a model of community assistance and empowerment to be more actively involved in utilizing all the potential and strength of assets owned by the community to create economic and social welfare. The results of this research, the community can take advantage of the opportunities and potential of their banana assets to be a product of Jenang made from banana as an icon of snacks from Jampet village.
\end{abstract}

Keywords: Utilization of Bananas, Jenang Banana, Asset-Based Community Development (ABCD)

\section{Pendahuluan}

Jampet merupakan sebuah desa yang terletak di Kabupaten Bojonegoro, tepatnya di kecamatan Ngasem. Desa Jampet adalah sebuah desa kecil yang masuk ke dalam wilayah administrasi Kecamatan Ngasem yang berpenduduk sekitar 4.405 jiwa dengan luas wilayah 3.800.000 M2. ${ }^{1}$ Pada mulanya desa Jampet merupakan bagian dari desa Wotanngare Kecamatan Kalitidu. ${ }^{2}$ Karena semakin lama semakin berkembang maka atas saran dan usul dari sesepuh desa, maka dibentuklah desa sendiri yang kemudian diberi nama dengan desa Jampet. ${ }^{3}$ Desa Jampet berbatasan dengan sebelah utara desa Wotanngare, sebelah timur berbatasan dengan desa Wadang, sebelah selatan berbatasan dengan desa Tengger, dan di sebelah barat juga berbatasan dengan desa Jelu. ${ }^{4}$

Kecamatan Ngasem termasuk daerah yang tergolong rendah pendapatan perekonomian dan sarana pembangunannya apabila dibandingkan dengan beberapa wilayah kecamatan lain di Kabupaten Bojonegoro. Namun demikian ternyata wilayah ini memiliki berbagai macam aset

\footnotetext{
${ }_{1}$ Profil Desa Jampet lihat dalam Sejarah Desa Jampet, n.d.

2 Wawancara dengan kepalan desa Jampet 20 Januari 2018

${ }^{3}$ Dokumen keadaan geografis Desa Jampet lihat dalam Keadaan Geografis Desa Jampet, n.d.

4 ibid
}

Volume 3, Number 1, Mei 2019|55

Pemanfaatan Aset Buah Pisang Lokal Menjadi Produk Jenang "Jepipet" di Desa Jampet Kecamatan Ngasem Kabupaten Bojonegoro 
sumber daya alam yang begitu banyak dan melimpah yang bisa dimanfaatkan untuk penguatan ekonomi dan pembangunan infrastruktur untuk kesejahteraan masyarakatnya.

Perekonomian di desa Jampet bergantung pada sektor pertanian paling utama. Di samping itu untuk menunjang perekonomian warga desa Jampet ditunjang dari sektor peternakan yang dikelola oleh beberapa anggota masyarakat desa, demikian juga yang tidak kalah pentingnya adalah sektor perdagangan yang berporos pada pasar desa Jampet yang berlokasi di jalan raya utama desa yang menghubungkan antara kecamatan Ngasem dan kecamatan Kalitidu. ${ }^{5}$

Seiring dengan perjalanan waktu, perekonomian masyarakat desa Jampet lambat laun telah menunjukkan perkembangan baik yang sangat signifikan. Hal itu dapat dibuktikan dengan berbagai produk unggulan yang muncul belakangan ini yang dihasilkan dari kerja bersama masyarakat dan perguruan tinggi -- salah satunya adalah UIN Sunan Ampel Surabaya--. Seperti halnya produk jajanan "Enderese" (sebuah jajanan khas produk masyarakat desa Bareng yang merupakan hasil kolaborasi kerja bersama antara masyarakat setempat dengan tim UIN Sunan Ampel Surabaya. Makanan olahan ini diproduksi dari tepung ketela yang merupakan aset alam yang banyak dihasilkan dari perkebunan desa Bareng dan beberapa desa sekitar wilayah kecamatan Ngasem. ${ }^{6}$

Masyarakat desa Jampet patut berbangga dengan dilaunchingnya sebuah produk makanan yang berupa jenang pisang khas Jampet ini. Produk ini adalah berupa jenang pisang yang dihasilkan dari proses diskusi, eksplorasi, dan discovery yang dilakukan secara intensif bersama tim UIN Sunan Ampel Surabaya dengan warga masyarakat desa Jampet.

Desa Jampet merupakan salah satu desa di wilayah kecamatan Ngasem yang cukup mengalami kemajuan pesat dalam pembangunan karena letaknya di sepanjang jalan utama yang menghubungkan kecamatan Ngasem ke arah kecamatan Kalitidu. Sampai saat ini, desa Jampet sudah hampir lima (5) tahun secara berturut-turut selalu dijadikan sebagai bagian dari mitra dan desa dampingan Lembaga Penelitian dan Pengabdian Kepada Masyarakat (LP2M) UIN Sunan Ampel Surabaya.

\section{Metode}

Penelitian ini menggunakan Asset Based Community-Driven Development (ABCD), adalah salah satu strategi penggerak komunitas secara berkala dalam masalah pengembangan masyarakat. Pendekatan pendampingan masyarakat ini mengupayakan pengembangan komunitas yang sejak dari awal menempatkan manusia agar dapat mengetahui apa yang menjadi kekuatan yang

\footnotetext{
5 Wawancara dengan kepala desa Jampet, tanggal 21 Januari 2018
} 
dimilikinya, serta segenap potensi dan aset yang dipunyainya untuk dapat dimanfaatkan. ${ }^{7}$ ABCD berfokus pada bagaimana caranya untuk menghubungkan atau mengenalkan suatu aset yang tidak disadari pada sebuah lingkungan yang lebih besar. Keunikan dari ABCD berada pada premis bahwa suatu komunitas dapat secara mandiri mengendalikan proses pengembangan komunitas tersebut dengan mampu mengidentifikasi dan memobilisasi keberadaan aset yang tidak disadari sebelumnya, dengan demikian mampu untuk membuat suatu peluang ekonomi. ${ }^{8}$

McKnight dan Kretzmen dari Northwestern University, berpendapat bahwa ABCD merupakan salah satu cara untuk memanfaatkan suatu aset yang tidak disadari yang ditujukan untuk suatu pengembangan masyarakat di sebuah daerah dengan pendekatan yang berbasis kebutuhan?. Peran perguruan tinggi dan pemerintah untuk terlibat dalam survai kebutuhan serta menganalisis sebuah problem dan mengidentifikasi solusi untuk pemenuhan kebutuhan masyarakat. ${ }^{10}$

Brown mengemukakan bahwa ABCD adalah upaya untuk menemukan akar sebuah kesuksesan dalam pemberdayaan masyarakat, bukan mencari akar permasalahan ${ }^{11}$. Lebih lanjut menurutnya; bila kita fokus pada masalah di masyarakat maka kita akan menemukan banyak masalah, akan tetapi bila kita fokus pada upaya mencari peluang untuk sukses, kita akan dapat menemukan akar penyebab kesuksesan. Sehinga motto ABCD adalah "mencari akar terjadinya kesuksesan dengan memanfaatkan peluang dengan aset yang ada", tidak mencari-cari masalah. ${ }^{12}$

Asset adalah segala sesuatu yang berharga, bernilai sebagai kekayaan atau perbendaharaan. Segala yang bernilai tersebut memiliki guna untuk memenuhi kebutuhan ${ }^{13}$. Hanya dengan mengetahui kekuatan dan aset diharapkan masyarakat dapat bersemangat untuk terlibat sebagai aktor dan oleh karenanya memiliki inisiatif dalam segala upaya perubahan. ${ }^{14}$

Untuk menggali potensi-potensi masyarakat selain model yang di atas, masih ada strategi lain yang digunakan oleh fasilitator yang dilakukan bersama masyarakat untuk terwujudnya

\footnotetext{
${ }^{7}$ Nadhir Salahuddin, Panduan KKN ABCD UIN Sunan Ampel Surabaya Asset Based Community-Driven Development (ABCD) (LP2M UIN Sunan Ampel Surabaya, 2015), 14.

${ }^{8}$ What Is Asset Based Community Development ABCD (Chicago: Depaul University, 2013), 1.

9 ABCD Institute, "What Is Asset Based Community Development (ABCD)," ABCD Toolkit (2016): 4, https://www.neighborhoodtransformation.net/pdfs/What_

is_Asset_Based_Community_Development.pdf\%5Cnhttp://www.abcdinstitute.org/docs/What

isAssetBasedCommunityDevelopment(1)(3).pdf.

10 Alison Mathie and Gord Cunningham, "From Clients to Citizens: Asset-Based Community Development as a Strategy for Community-Driven Development," Coady International Institute 13, no. 5 (2003): 4.

11 Anna Kajumulo Tibaijuka, "ABCD and the Enabling Approach: Complimentary Strategies for Developing Countries," Agents rather than patients-realizing the potential for asset-based community development (2003).

12 Christopher Dureau, "Pembaru Dan Kekuatan Lokal Untuk Pembangunan," TT: Australian Community Development and Civil Society Strengthening Scheme (ACCESS) Phase II (2013): 20.

${ }^{13}$ Sherianne Kramer et al., "The Philosophical Assumptions, Utility and Challenges of Asset Mapping Approaches to Community Engagement," Journal of Psychology in Africa 22, no. 4 (2012): 537-544.

${ }^{14}$ Salahuddin, Panduan KKN ABCD UIN Sunan Ampel Surabaya Asset Based Community-Driven Development (ABCD).
} 


\section{ENGAGEMENT}

JurnalPengabdian KepadaMasyarakat

ISSN : 2579-8375 (Print)

ISSN : 2579-8391 (Online)

pendampingan yang akan dilakukan bersama ${ }^{15}$. Dalam pendekatan $\mathrm{ABCD}$ terdapat empat kunci utama untuk melakukan suatu pendampingan masyarakat yaitu, ${ }^{16}$

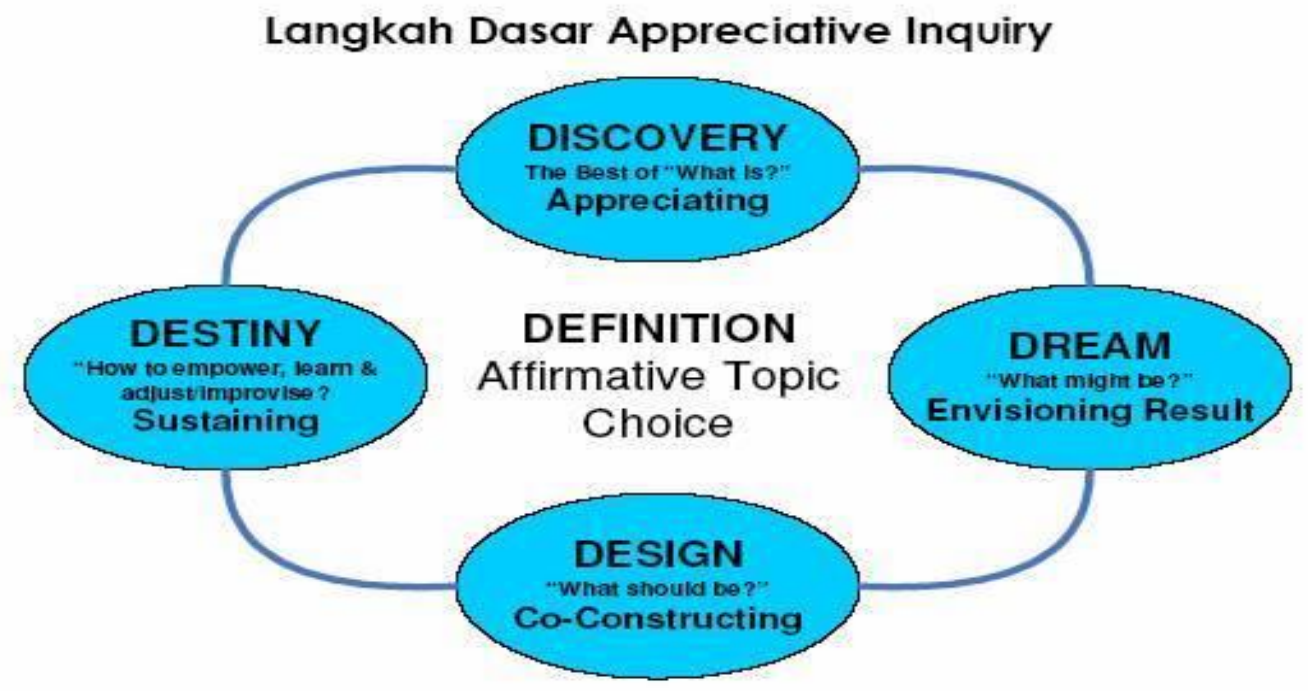

\section{Discovery}

Pada tahap ini dilakukan upaya inkulturasi, yaitu sebuah cara untuk menjalin keterbukaan dan saling percaya, hal ini juga merupakan upaya untuk mewujudkan proses komunikasi yang baik dengan masyarakat ${ }^{17}$. Untuk itu, keterampilan berkomunikasi menjadi sangat dominan. Cara terbaik melakukan akulturasi adalah bergabung menjadi bagian dari segala rutinitas yang melibatkan orang banyak pada komunitas mitra misalnya seperti mengikuti shalat berjama'ah, pengajian, mengikuti kegiatan karang taruna, atau mengajar di sekolah.

Penggunaan bahasa yang sesuai budaya lokal komunitas mitra juga harus dipertimbangkan. Apabila kepercayaan sudah terbangun, maka informasi akan mengalir jauh lebih mudah, sehingga tahapan-tahapan berikutnya dalam pemberdayan komunitas ini akan lebih cepat dan terarah dengan baik. ${ }^{18}$

Pada tahap ini, kegiatan yang dilakukan dapat berupa kegiatan pemetaan asset. Kata asset dipahami tidak selalu dalam bentuk uang. Aset dapat berupa kisah sukses, sejarah komunitas, asosiasi, institusi bahkan warga komunitas mitra merupakan asset yang utama ${ }^{19}$. Adapun alat-alat yang dapat digunakan untuk membantu proses pemetaan antara lain Appreciative Inquiry, Community Map, Transect, Individual Skill Inventory, dan Analisa Sirkulasi Keuangan Masyarakat.

${ }^{15}$ Kramer et al., "The Philosophical Assumptions, Utility and Challenges of Asset Mapping Approaches to Community Engagement."

${ }^{16}$ Salahuddin, Panduan KKN ABCD UIN Sunan Ampel Surabaya Asset Based Community-Driven Development (ABCD).

${ }^{17}$ What Is Asset Based Community Development ABCD.

${ }^{18}$ Dureau, "Pembaru Dan Kekuatan Lokal Untuk Pembangunan."

19 Alison Mathie and Gord Cunningham, "From Client To Citizens: Asset-Based Community Development as a Strategy for Community Driven Development," Coady International Institute (Antigonish, Canada, 2002).

Volume 3, Number 1, Mei $2019 \mid 58$

Pemanfaatan Aset Buah Pisang Lokal Menjadi Produk Jenang "Jepipet" di Desa Jampet Kecamatan Ngasem Kabupaten Bojonegoro

Abid Rohman, Aliyah, Fikri Aji Wicaksosmo 


\section{Dream}

Dream adalah strategi untuk mengajak masyarakat menemukan impian-impiannya. Kadangkala masyarakat tidak tahu harus bagaimana dalam menentukan keinginan-keinginannya di masa yang akan datang ${ }^{20}$. Melalui metode ini masyarakat diajak untuk bersama-sama mengidentifikasi harapan-harapannya serta segala perubahan dan kesuksesan yang ingin dicapainya di masa yang akan datang. Metode ini akan mengarahkan masyarakat untuk mencapai sebuah keberhasilan dan perubahan yang lebih baik dimasa akan datang dengan lebih fokus. ${ }^{21}$

\section{Design}

Pada proses ini masyarakat diajak untuk bersama-sama menentukan strategi untuk mencapai keinginan dan cita-citanya. Setelah masyarakat secara bersama-sama dapat menentukan prioritas keinginan dan harapan-harapannya ${ }^{22}$. Langkah berikutnya adalah menentukan strategi yang paling tepat untuk menuju pada keberhasilan harapan-harapan itu. ${ }^{23}$

\section{Destiny}

Tahap ini merupakan proses melaksanakan program kerja dari yang telah dirumuskan bersama masyarakat untuk memenuhi keinginan masyarakat. Model ini memusatkan posisinya pada kekuatan dan keberhasilan diri dan komunitas yang bertujuan merangsang kreativitas, inspirasi, dan inovasi masyarakat untuk mendapatkan kembali masa kejayaan yang pernah mereka peroleh dahulu ${ }^{24}$. Kemampuan terkait potensi, kekuatan, keberhasilan, serta dibarengi dengan asset yang mereka miliki akan memberikan energi positif untuk membantu dan mengembalikan kekuatan dan keberhasilan mereka dalam mengubah cara pandang terhadap segala sesuatu menjadi lebih baik. Ada beberapa prinsip lain yang dapat digunakan dalam pengembangan masyarakat berbasis ABCD, diantaranya: (a). Setengah terisi lebih berarti (Half Full Half Empty) prinsip ini mengindikasikan akan pentingnya semangat berpikiran positif; (b). Semua punya potensi (Nobody Has Nothing), prinsip ini menggambarkan bahwa semua orang punya kemampuan, punya kesempatan untuk berhasil dan sukses; (c). Partisipasi (Participation), prinsip ini menjelaskan untuk terwujudnya peran dari seluruh komponen masyarakat; (d). Kemitraan (Partnership), prinsip ini menegaskan akan pentingnya terjalin kemitraan yang berjalan secara setara, adil dan baik antar berbagai komponen yang ada di masyarakat; (e). Berawal dari masyarakat (Endogenous), prinsip ini mengakui bahwa masyarakat adalah sumber belajar, masyarakat memiliki otoritas untuk

\footnotetext{
${ }^{20}$ Claudia Dolezal and Peter M Burns, “ABCD to CBT: Asset-Based Community Development's Potential for Community-Based Tourism,” Development in Practice 25, no. 1 (2015): 133-142.

${ }^{21}$ Salahuddin, Panduan KKN ABCD UIN Sunan Ampel Surabaya Asset Based Community-Driven Development (ABCD).

${ }^{22}$ Tibaijuka, "ABCD and the Enabling Approach: Complimentary Strategies for Developing Countries."

${ }^{23}$ Salahuddin, Panduan KKN ABCD UIN Sunan Ampel Surabaya Asset Based Community-Driven Development (ABCD).

${ }^{24}$ Dureau, "Pembaru Dan Kekuatan Lokal Untuk Pembangunan."
} 
mengkreasi ilmu pengetahuannya secara mandiri; dan (f). Menuju sumber senergi (Heliotropic), Prinsip ini menegaskan akan pentingnya kekuatan yang dimiliki masyarakat untuk dikelola dalam mewujudkan perubahan yang lebih baik. ${ }^{25}$

\section{Hasil dan Diskusi}

Seringkali warga masyarakat tidak menyadari akan potensi dan asset yang mereka miliki, sehingga mereka selalu merasa lemah dan tidak mampu berbuat banyak untuk mengembangkan kehidupannya. Dalam proses pendampingan ini ada beberapa langkah yang dilakukan diantaranya: langsung menemui warga dengan cara berkomunikasi yang sebenarnya mereka tidak menyadari sedang menjadi nara sumber. Disamping itu beberapa angket disebarkan ke beberapa informan/responden untuk lebih menguatkan data khususnya dalam proses pelaporan.

Mendampingi warga untuk menyadari potensi dan aset yang mereka miliki adalah sebuah pengalaman yang menakjubkan, bayangkan mereka yang setiap hari bertemu dengan alam sekitar, bergaul dengan masyarakat sesungguhnya memiliki potensi dan juga aset yang luar biasa besarnya, tetapi mereka belum menyadari akan hal tersebut. Adapun proses-proses pendampingan yang dilakukan oleh tim pendamping dari UIN Sunan Ampel Surabaya terhadap masyarakat desa Jampet adalah sebagai berkut:

\section{Inkulturasi dan upaya menemukan kekuatan}

Dalam metode ini langkah awal yang dilakukan adalah penggalian Aset, yang dalam hal ini informasi tentang Aset desa Jampet yang diperoleh dari kepala desa dan aparat desa Jampet pada waktu pertemuan penyambutan tim pendamping UIN Sunan Ampel Surabaya di balai desa. Dengan informasi awal itulah sebagai bekal tim pendamping UIN Sunan Ampel Surabaya untuk menggali lebih jauh untuk menemukan informasi lebih detail terkait asset yang dimiliki oleh masyarakat desa Jampet. Pemetaan asset yang dilakukan oleh warga masyarakat desa Jampet dengan difasilitasi oleh tim pendamping UIN Sunan Ampel Surabaya diawali dengan beberapa kegiatan FGD (Focus Group Discussion) sebagai berikut:

Pertama, Pemetaan aset desa Jampet.

Desa Jampet merupakan desa yang terletak pada salah satu Kecamatan yang ada di Kabupaten Bojonegoro, yaitu Kecamatan Ngasem. Desa Jampet mempunyai wilayah yang cukup luas, yaitu dengan luas wilayah $3.800 .000 \mathrm{~m}^{2}$. Desa Jampet saat ini mempunyai 3 (tiga) dusun, yaitu dusun Jampet (RT 1 - RT 13), dusun Karanganyar (RT 14), dan dusun Sambirejo (RT 15 - RT 19). Sehingga Jampet mempunyai 19 (sembilan belas) RT dan 4 (empat) RW yang tersebar didalam

${ }^{25}$ Salahuddin, Panduan KKN ABCD UIN Sunan Ampel Surabaya Asset Based Community-Driven Development (ABCD). 
3 (tiga) dusun.

Setiap wilayah selalu mempunyai batas wilayah administrasi masing-masing. Adapun batasbatas desa Jampet ini adalah sebagai berikut: Sebelah utara: berbatasan dengan desa Wotanngare kecamatan Kalitidu. Sebelah selatan: berbatasan dengan desa Jelu dan desa Tengger Kecam,atan Ngasem. Sebelah timur: berbatasan dengan desa Wadang Kecamatan Ngasem Sebelah barat: berbatasan dengan desa Jelu kecamatan Ngasem.

Desa Jampet mempunyai letak yang mudah diakses jalannya. Untuk menjangkau Desa Jampet dapat melalui 2 (dua) jalur yang berbeda, yaitu jalur utara melalui Kecamatan Kalitidu, dan jalur selatan melalui Kecamatan Dander. Begitupun juga dengan jarak Jampet dengan Bojonegoro Kota yang tidak terlalu jauh, yang dapat dijangkau \pm 30 menit saja.

Desa Jampet merupakan desa yang terletak sangat strategis, karena berbatasan langsung dengan Kecamatan Kalitidu yang akses utamanya adalah ke jalan raya utama. Desa Jampet merupakan desa yang mempunyai pasar sendiri dengan nama dari Desa sendiri yaitu Pasar Jampet. Pasar tersebut sangat strategis letaknya dengan Desa sebelah, yaitu Desa Jelu yang banyak berbelanja pagi di pasar tersebut. Sehingga pasar tersebut memberikan manfaat yang banyak bagi warga Desa Jampet, seperti warga Jampet yang berjualan setiap paginya disana meskipun hanya buka pada jam pagi saja, akan tetapi hal itu sudah meringankan warga untuk berbelanja di setiap paginya. Karena tidak perlu pergi ke pasar besar yang berada di Kalitidu dengan jarak tempuh yang cukup lama yaitu \pm 10 menit.

Kondisi Desa Jampet ini adalah masih banyak dijumpai lahan kosong yang tertanami oleh pohon (pisang, jati, jambu, mahoni, jagung, bambu, dan lain-lain) dan persawahan. Cukup banyak juga pemukiman, akan tetapi lahan samping kanan kiri dari rumah warga juga masih tergolong luas. Dengan banyaknya lahan yang kosong tersebut, banyak warga yang memanfaatkan sebagai mata pencaharian juga, yaitu hasil perkebunan mereka, dipanen dan dijual ke pasar Jampet, seperti: rebung, daun ketela, daun kunci, jagung, pandan, dan lain-lainnya.

Kedua, Demografis desa Jampet

Dalam sebuah wilayah di Indonesia tentu terdapat banyak keragaman, dari berbagai segi misal bahasa, adat, dan agama. Akan tetapi keragaman yang ada di Indonesia itu dijadikan sebagai keindahan. Sebagaimana semboyan Bangsa Indonesia yang sampai saat ini tetap dipegang teguh, yaitu: Bhinneka Ika Tunggal Ika yang berarti “Berbeda-beda tetapi tetap satu jua."

Keragaman yang ada di Indonesia seperti yang telah dijelaskan diatas, terdapat di Desa Jampet ini. Desa Jampet bukanlah sebuah desa yang didalamnya hanyalah terdapat orang-orang Islam saja. Akan tetapi di beberapa titik terdapat beberapa orang yang beragama selain Islam. 
Mereka pun saling menghormati dan menjaga satu sama lain.

Menurut informasi yang didapat dari salah satu tokoh warga desa Jampet, bahwa:

"beberapa orang yang beragama selain Islam sangat menghormati kegiatan Islam di Jampet. Bahkan mereka meniru tradisi-tradisi Islam yang ada di Jampet, seperti syukuran. Mereka melakukan syukuran layaknya orang Islam pada umumnya, akan tetapi yang membedakan hanyalah unsur do'a saja. Rasa toleransi di Jampet ini sangat tinggi, seperti yang pernah dilakukan umat beragama lain di Jampet ini adalah ketika Idul Fitri. Setiap malam menjelang Idul Fitri, warga Jampet melakukan takbir keliling. Mereka umat beragama lain, justru memberikan semangat pada umat Islam.

Jampet ini merupakan desa yang mempunyai penduduk cukup banyak, lebih dari 4.405 jiwa berda di desa ini. Terdapat 1.063 Kartu Keluarga (KK) pada tahun 2016. Dari 1.063 KK yang ada, jumlah penduduk laki-laki dan perempuan di sini termasuk seimbang. Jumlah penduduk laki-laki sebanyak 1.671 jiwa dan jumlah penduduk perempuan sebanyak 1.729 jiwa, dengan itu total penduduk di Desa Jampet sebanyak 3.400 jiwa pada tahun 2016 saat itu"26

Dari penjelasan tersebut dapat disimpulkan bahwa, aset berupa jumlah penduduk yang cukup banyak, dan adanya varian latar belakang pendidikan warga desa Jampet secara garis besar dapat dijadikan aset desa, sehingga dapat dipertimbangkan untuk dilakukannya sebuah aksi bersama yang lebih nyata guna meraih perubahan dan perbaikan masyarakat yang lebih baik secara bertahap.

\section{Aset Ekonomi Desa}

Desa Jampet termasuk salah satu desa yang masih luas lahan pertaniannya, oleh karena itu sebagian besar warga Jampet bermata pencaharian sebagai petani. Meskipun sebagian besarnya adalah petani, maka tidak menutup kemungkinan juga beberapa warga yang menggantungkan dirinya dengan usahanya sendiri. Di Jampet ini terdapat beberapa orang yang mempunyai usaha sendiri dirumahnya, seperti: pembuatan sangkar burung perkutut, budidaya jamur, dan budidaya lele. Selain itu ada juga yang membuka toko perabotan rumah tangga, toko material bangunan, penjual sayur mayur di pasar, berjualan gorengan, dan membuka toko kecil di rumahnya.

Bagi mereka yang mempunyai kebun disamping atau dibelakang rumahnya, yang atas kepemilikan pribadi sangat banyak dijumpai tanaman pisang. Dengan hasil pisang tersebut, pemilik kebun menjual pisang yang dipanen untuk dijual ke pasar Jampet, pasar Kalitidu, dan bahkan juga dijual ke pengepul untuk dijual ke Kota Surabaya. Penjualan yang dilakukan itu hanyalah penjualan berupa pisang yang masih utuh berupa tandanan, belum tersentuh olahan manusia sama sekali, sehingga harga pisang relative murah. Kemudian dengan hasil kebun atau hasil pertaniannya yang

${ }^{26}$ Wawancara dengan tokoh masyarakat (Pak Wo) desa Jampet, tanggal 20 Januari 2018 
tidak seberapa, mereka memanfaatkannya hanya untuk mencukupi kebutuhan pokok saja karena belum memadai untuk dilakukan penjualan. Dari sinilah muncul gagasan untuk memanfaatkan buah pisang asli Jampet untuk diolah dan diproses lebih baik guna menambah penghasilan keluarga masyarakat.

\section{Menentukan Mimpi Bersama Masyarakat}

Masyarakat desa Jampet, bersama tim pendamping UIN Sunan Ampel Surabaya seringkali melakukan kegiatan FGD baik secara formal di balai desa Jampet, di forum pertemuan ibu-ibu PKK, maupun secara informal bertemu di pekarangaan rumah, sawah, dan di masjid maupun musholla untuk bercerita harapan- harapan yang diinginkan dengan dasar aset-aset yang mereka miliki.

Dalam hal ini, pemilihan dan penentuan harapan yang disepakati untuk diupayakan adalah adanya penambahan pemasukan penghasilan dengan memanfaatkan aset buah pisang yang ada di pekarangan rumah yang ada hampir di setiap rumah penduduk desa Jampet untuk dijadikan sebagai media yang dapat menghasilkan tambahan pendapatan rumah tangga.

\section{Perencanaan Aksi Untuk Mewujudkan Impian}

Masyarakat desa jampet dengan difasilitasi tim pendamping UIN Sunan Ampel Surabaya berdiskusi dan melakukan experimen bersama untuk membuat jajanan khas dari buah pisang Jampet. Setelah percobaaan itu dilakukaan beberapa kali dengan dukungan ibu-ibu PKK desa Jampet, akhirnya diputuskan untuk melakukan aksi kongkrit dengan menjadikan buah pisang Jampet menjadi jajanan khas desa Jampet berupa jenang pisang jampet (JEPIPET).

Dewasa ini sudah ada beberapa produk jajanan yang telah menjadi ikon desa di wilayah kecamatan Ngasem Kabupaten Bojonegoro, diantaranya adalah jajanan "ENDERESE”. Prodak ini sekarang sudah mulai dikenal dalam skala nasional, hal ini tidak lain adalah hasil kerja keras yang diinisiasi oleh tim pendamping UIN Sunan Ampel Surabaya dan bekerja sama dengan masyarakat desa Bareng pada satu tahun yang lalu.

Pada awal tahun ini, masyarakat desa Jampet --yang berlokasi di sebelah utara desa Barengkecamatan Ngasem Kabupataen Bojonerogo-- juga patut berbangga dengan dilaunchingnya sebuah produk unggulan makanan khas dari desa jampet yang berupa Jenang pisang khas Jampet yang dikenal dengan sebutan "JEPIPET". Produk unggulan ini adalah berupa Jenang Pisang khas yang dihasilkan dari proses diskusi, eksplorasi, discovery yang dilakukan secara intensif dan bersamasama antara tim pendamping UIN Sunan Ampel Surabaya dan masyarakat desa Jampet kecamatan 
Ngasem Kabupaten Bojonegoro.

Jampet merupakan salah satu desa di wilayah kecamatan Ngasem yang cukup mengalami kemajuan pesat dalam pembangunan karena letaknya di sepanjang jalan utama yang menghubungkan kecamatan Ngasem ke arah kecamatan Kalitidu. Sesuai dengan kondisi masyarakat desa yang sudah mulai membaik secara ekonomi dan pembangunannya, maka penggunaan pendekatan Asset-Based Community Driven-Development (ABCD) dirasa sangat tepat untuk dijadikan untuk digunakan.

Setelah tim pendamping UIN Sunan Ampel Surabaya melakukan proses inkulturasi pada tahap discovery untuk menggali data bersama warga masyarakat, maka diketemukanlah beberapa asset yang dimililiki oleh warga masyarakat desa Jampet. Salah satu aset yang dimiliki oleh warga masyarakat desa tersebut adalah; banyaknya pohon pisang yang sudah berbuah di sekitar pekarangan rumah warga masyarakat. Maka muncullah gagasan dari warga masyarakat desa Jampet dengan difasilitasi oleh tim pendamping UIN Sunan Ampel Surabaya untuk mewujudkan sebuah impian (dream) dengan menjadikan buah pisang yang sudah matang agar menjadi sesuatu yang lebih bernilai secara ekonomis bagi warga.

Gagasan itu kemudian bergulir akhirnya disepakati oleh warga masyarakat dan tim pendamping untuk dijadikan makanan/jajanan yang khas menjadi ikon desa Jampet yang dikenal dengan nama "JEPIPET" (Jenang Pisang Jampet), hal ini tidak lain juga karena didorong oleh kondisi masyarakat desa Jampet yang rata-rata memiliki banyak sekali pohon pisang di pekarangan rumahnya, maupun juga di sekitar kebun dan sawah yang mereka miliki. Jika ada pertanyaan, apakah di jampet sudah ada yang produksi jenang pisang sebelumnya?, maka jawabannya adalah belum ada. Selama ini, warga masyarakat Jampet hanya menjual pisang mentah dengan harga yang lebih murah di tengkulak, ataupun kalau mereka menjualnya dalam kondisi matang bisa dipastikan tidak akan bertahan lama cepat lembek dan juga dan kurang mendapat nilai ekonomi yang lebih, ataupun bahkan mereka sering membuangnya karena sudah membusuk.

Dengan melihat banyaknya asset berupa buah pisang yang ada di desa Jampet ini, maka tercetuslah ide mahasiswa dan masyarakat untuk mengembangkan asset pisang yang kurang bernilai secara ekonomis, kemudian menjadi sesuatu yang lebih berhaga secara ekonmis dengan mendatangkan pundi-pundi rupiah yang menggiurkan. Hal ini bisa dilakukan karena bahan baku jenang pisang Jampet sangat mudah diperoleh di sekitar wilayah desa ini.

Dengan bahan yang tidak terlalu mahal dan sangat ekonomis ini maka kemudian tim pendamping ini berkolaborasi dengan warga desa Jampet untuk melakukan beberapa kali uji coba yang akhirnya dapat memproduksi secara lebih masal bersama-sama Ibu-Ibu PKK di balai desa 
Jampet pada hari Sabtu tanggal 20 Januari 2018.

Saat ini, JEPIPET sudah dikenal di seluruh warga masyarakat Jampet, apalagi bapak Lurah desa Jampet mendukung secara penuh untuk proses kelanjutannya dengan melibatkan Badan Usaha Milik Desa (BUMDES) untuk mengelola lebih serius dalam produksi jajanan ini ke depan, serta mengupayakan distribusi pemasarannya sehingga menjadi ikon desa Jampet yang bernilai secara ekonomis demi menambah kesejahteraan kehidupan warga masyarakatnya. ${ }^{27}$ Bahkan pihak kecamatan Ngasem sudah mendengar dan pernah memesan produk ini, sehingga kemudian berjanji untuk mendukung program ini dengan membantu secara penuh untuk kepengurusan izin ke Departemen Kesehatan (Depkes) RI dan Dinas Perindustrian dan Perdagangannya (Disperindag) RI. ${ }^{28}$

Adapun komposisi yang digunakan untuk membuat JEPIPET adalah; tepung beras rose brand, santan kanil kelapa, gula pasir, gula merah, pandan, garam, dan yang terpenting adalah pisang, yang kini dipakai adalah pisang raja yang sudah benar-benar matang. Cara pembuatannya sama seperti pembuatan jenang pada umumnya, yakni santan kanil kelapa direbus dengan gula merah, gula pasir, garam, dan pandan hingga benar-benar matang dan mengental. Setelah itu masukan adonan tepung beras rose brand yang sudah di campur dengan pisang yang sudah diblender terlebih dahulu. Semuanya dicampur menjadi satu diaduk di wajan besar selama \pm 3 jam untuk memberikan hasil yang sangat baik dan menjadikan JEPIPET tahan lebih lama tanpa bahan pengawet.

Dalam hal upaya pemasaran jajanan ini di masyarakat desa, tim pendamping UIN Sunan Ampel Surabaya bersama-sama ibu-ibu PKK desa Jampet mengupayakan dengan membuat packaging JEPIPET dengan membuat bungkus yang unik dan ekonomis. Bahannya dibuat dari kertas yang ramah lingkungan dan tampilannya yang menarik membuat jajanan bernilai lebih elegan dan higienis. Kertas yang digunakan ialah samson craft yang kemudian dipotong menjadi 16 bagian. Print kertas tersebut dengan pola tas yang telah didesain menggunakan coreldraw. Lipat kertas tersebut sesuai pola dan rekatkan bagian-bagiannya dengan lem kertas. Alat pelengkap yang digunakan ialah tali kur warna coklat dan perpurator.

Upaya untuk melakukan pengenalan dan pemasaran jajanan khas “Jepipet” ini tidak hanya berhenti di sini, akan tetapi tim pendamping UIN Sunan Ampel Surabaya bersama warga masyarakat telah melakukan pengenalan produk dengan memasarkannya di beberpa outlite/toko

\footnotetext{
27 Wawancara dengan Kepala desa Jampet, Bpk Sukisno, dalam sesi diskusi persiapan launching "Jepipet" sebagai ikon desa Jampet di balai desa Jampet, 25 Januari 2018

${ }^{28}$ Tim pendamping UIN Sunan Ampel Surabaya mendapat undangan langsung dari pihak kecamatan Ngasem kabupaten Bojonegoro untuk menjelaskan lebih lanjut hasil kolaborasi kerja bersama antara tim pendamping dengan Warga masyarakat desa Jampet, bahkan dalam hal ini pihak Pemerintah Kecamatan Ngasem secara langsung memesan sampel/contoh produk "Jepipet" untuk dikenalkan di wilayah kecamatan Ngasem.
} 
yang ada di tempat-tempat wisata di sekitar kecamatan Ngasem seperti halnya, di tempat pariwisata Kayangan Api desa Dander Kabupaten Bojonegoro.

Adapun kisaran keuntungan dalam produksi JEPIPET adalah sebagai berikut; pada setiap resep adonannya menghabiskan \pm Rp 70.000.-, adukan yang sudah jadi bisa dicetak bundar untuk pengemasannya, yang nanti menjadi \pm 170 biji. Dan selanjutnya dikemas dalam tas dari kertas dengan jumlah isi 8 biji. Untuk penjualan dibandrol dengan harga yang sangat ekonomis yaitu Rp 5.000,-/tas. Sehingga warga masyarakat mendapaatkan keuntungan uang sebesar \pm Rp 170.000.setiap kali adonan.

\section{Kesimpulan}

Program pendampingan dengan menggunakan pendekatan Asset-based Community Development $(\mathrm{ABCD})$ ini telah mampu menyadarkan warga untuk mengenali kekuatan, potensi yang dimikinya kembali guna membuat sebuah perubahan dan kemajuan baginya. Warga merasa yakin akan kemampuan yang dimilikinya, dan mereka menyadari bahwa pengetahuan ternyata dapat digali dari mereka, hal ini memberikan pengalaman baru dan keyakinan bagi mereka bahwa mereka adalah juga termasuk produsen ilmu pengetahuan. Pertumbuhan ekonomi masyarakat desa Jampet semakin membaik dengan berusaha memanfaatkan aset lokal desa "berupa buah pisang"--- yang selama ini dianggap remeh, sesuatu yang biasa, akan tetapi bila hal itu dapat dilakukan dengan kesadaran penuh melalui penelitian bersama dan aksi bersama secara partisipatif antara mereka dan perguruan tinggi akhirnya dapat menghasilkan sesuatu yang lebih bermakna bagi kehidupan yang nyata bagai warga masyarakat desa Jampet dan sekitarnya.

\section{Daftar Referensi}

ABCD Institute. "What Is Asset Based Community Development (ABCD)." $A B C D$ Toolkit (2016): $\quad 4.4$ https://www.neighborhoodtransformation.net/pdfs/What_ is_Asset_Based_Community_Development.pdf\% 05 Cnhttp://www.abcdinstitute.org/docs/ What isAssetBasedCommunityDevelopment(1)(3).pdf.

Dolezal, Claudia, and Peter M Burns. “ABCD to CBT: Asset-Based Community Development's Potential for Community-Based Tourism.” Development in Practice 25, no. 1 (2015): 133-142. Dureau, Christopher. "Pembaru Dan Kekuatan Lokal Untuk Pembangunan." TT: Australian Community Development and Civil Society Strengthening Scheme (ACCESS) Phase II (2013).

Kramer, Sherianne, Taryn Amos, Sandy Lazarus, and Mohamed Seedat. "The Philosophical Assumptions, Utility and Challenges of Asset Mapping Approaches to Community 


\section{ENGAGEMENT}

GurnalPengabdianKepadaMasyarakat

ISSN : 2579-8375 (Print)

ISSN : 2579-8391 (Online)
This work is licensed under a Creative Commons Attribution-ShareAlike 4.0 International License. CC BY SA

Engagement." Journal of Psychology in Africa 22, no. 4 (2012): 537-544.

Mathie, Alison, and Gord Cunningham. "From Client To Citizens: Asset-Based Community

Development as a Strategy for Community Driven Development." Coady International Institute.

Antigonish, Canada, 2002.

- "From Clients to Citizens: Asset-Based Community Development as a Strategy for

Community-Driven Development." Coady International Institute 13, no. 5 (2003): 474-486.

Salahuddin, Nadhir. Panduan KKN ABCD UIN Sunan Ampel Surabaya Asset Based Community-Driven

Development (ABCD). LP2M UIN Sunan Ampel Surabaya, 2015.

Tibaijuka, Anna Kajumulo. "ABCD and the Enabling Approach: Complimentary Strategies for

Developing Countries." Agents rather than patients-realizing the potential for asset-based community development (2003).

Keadaan Geografis Desa Jampet, n.d.

Sejarah Desa Jampet, n.d.

What Is Asset Based Community Development ABCD. Chicago: Depaul University, 2013. 